\title{
HIGH-QUALITY Ni-Fe/Cu MULTILAYER FILMS WITH ANTIFERROMAGNETIC COUPLING
}

\author{
F. Stobiecki, J. Dubowik, T. Luciński, B. Szymański, \\ Institute of Molecular Physics, Polish Academy of Sciences \\ Smoluchowskiego 17, 60-179 Poznań, Poland
}

H. Rohrmann, K. RöLL

University of Kassel, FB Physik, 34109 Kassel, Germany

AND M. SchmidT

Institute of Physics, A. Mickiewicz University, 60-780 Poznan, Poland

We report structural and magnetic properties of $\mathrm{Ni}_{83} \mathrm{Fe}_{17} / \mathrm{Cu}$ multilayer films with various buffer layer and sublayer thicknesses of copper $d_{\mathrm{Cu}}$ and Permalloy $d_{\mathrm{Py}}$ deposited by face-to-face sputtering. The following features prove a good quality of our films: a well-layered structure, complete antiferromagnetic coupling with a low coupling strength $\left(2 \times 10^{-5} \mathrm{~J} / \mathrm{m}^{2}\right.$ for $d_{\mathrm{Cu}}=1 \mathrm{~nm}$ and $10^{-6} \mathrm{~J} / \mathrm{m}^{2}$ for $d_{\mathrm{Cu}}=2.1 \mathrm{~nm}$ ) and a low coercive field which make them attractive for possible applications as giant magnetoresistance sensors.

PACS numbers: $76.50 .+\mathrm{g}, 75.50 . \mathrm{Tt}$

Recently, there has been a considerable interest in magnetic and magnetotransport properties of $\mathrm{Py} / \mathrm{Cu}$ and $\mathrm{Py} / \mathrm{Au}$ ( $\mathrm{Py}=$ Permalloy) multilayers (Mls) [1-6]. Much of this interest has focused on developing Mls with the highest possible giant magnetoresistance (GMR), a low antiferromagnetic coupling strength $\left(J_{\mathrm{AF}}\right)$ with a high fraction of antiferromagnetically $(\mathrm{AF})$ coupled regions $F_{\mathrm{AF}}=$ $\left(1-M_{\mathrm{R}} / M_{\mathrm{S}}\right)\left(M_{\mathrm{R}}, M_{\mathrm{S}}\right.$ are the remanence and saturation magnetization) and a low coercive field $H_{\mathrm{C}}$. Since the results obtained by several authors with the use of different deposition techniques vary [1-5], the magnetic properties of $\mathrm{Py} / \mathrm{Cu} \mathrm{Mls}$ seem to be very sensitive to the deposition and growth conditions. In the present paper we report on magnetic and structural properties of $\mathrm{Si}(100) / \mathrm{B} /(\mathrm{Py} / \mathrm{Cu})_{N}$ Mls (B - buffer layer with a thickness $d_{\mathrm{B}}, \mathrm{Py}=\mathrm{Ni}_{83} \mathrm{Fe}_{17}, N-$ number of periods) with various sublayers thicknesses of $\left.\mathrm{Cu} d_{\mathrm{Cu}}\right)$ and Permalloy $\left(d_{\mathbf{P}_{\mathbf{y}}}\right)$ obtained by the face-to-face sputtering technique [7]. The magnetic properties of the samples were determined from the hysteresis loops measured with a vibrating sample magnetometer (VSM) and magneto-optical Kerr effect (MOKE). The well-defined 

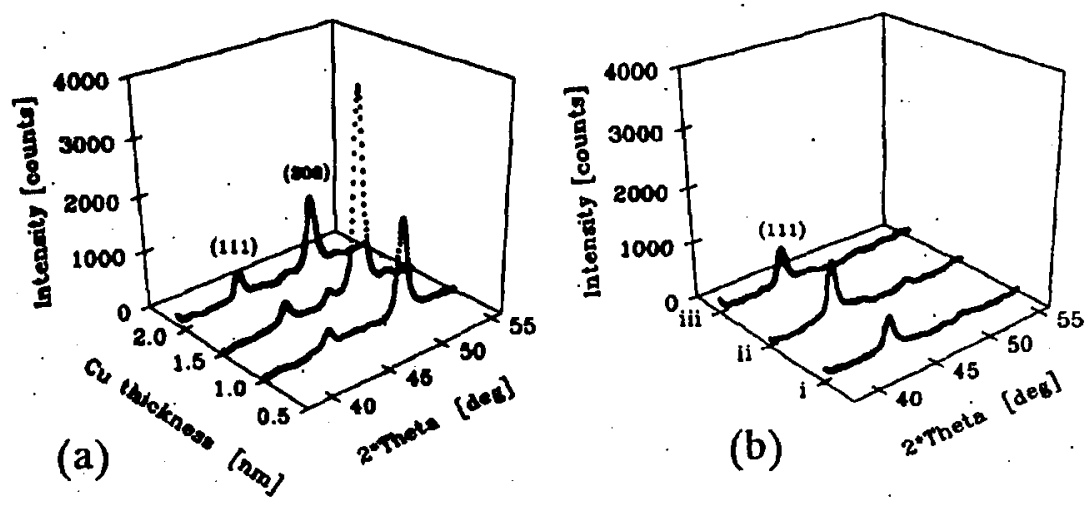

Fig. 1. X-ray diffraction patterns for: (a) $\mathrm{Si}(100) / \mathrm{Cu}-20 \mathrm{~nm} /(\mathrm{Py}-2.0 \mathrm{~nm} / \mathrm{Cu}$ $\left.-d_{\mathrm{Cu}}\right)_{100}$, (b) (i) $\mathrm{Si}(100) /(\mathrm{Py}-2.0 \mathrm{~nm} / \mathrm{Cu}-2.1 \mathrm{~nm})_{100}$, (ii) $\mathrm{Si}(100) / \mathrm{SiO}_{2} / \mathrm{Cu}-$ $20 \mathrm{~nm} /(\mathrm{Py}-2.0 \mathrm{~nm} / \mathrm{Cu}-2.1 \mathrm{~nm})_{100}$, (iii) $\mathrm{Si}(100) / \mathrm{Py}-5 \mathrm{~nm} /(\mathrm{Py}-2.0 \mathrm{~nm} / \mathrm{Cu}-$ $2.1 \mathrm{~nm})_{100}$.
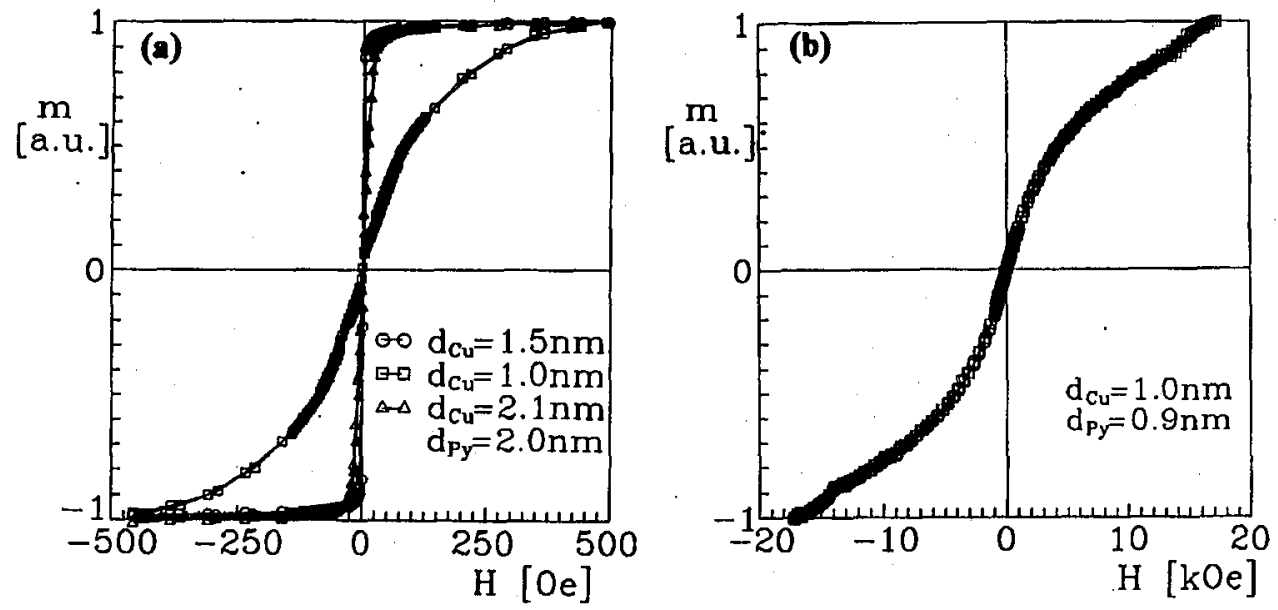

Fig. 2. (a) The fraction $1-M_{\mathrm{R}} / M_{\mathrm{S}}$ of antiferromagnetically coupled part of the multilayer as a function of Cu sublayer thickness $d_{\mathrm{Cu}}$ for Mls: (i) $\mathrm{Si}(100) / \mathrm{Cu}-20 \mathrm{~nm} /$ $\left(\mathrm{Py}-\mathrm{d}_{\mathrm{Py}} / \mathrm{Cu}-d_{\mathrm{Cu}}\right)_{100}$, (ii) $\mathrm{Si}(100) / \mathrm{SiO}_{2} / \mathrm{Py}-5 \mathrm{~nm} /\left(\mathrm{Py}-d_{\mathrm{Py}} / \mathrm{Cu}-d_{\mathrm{Cu}}\right)_{40}$, (iii) $\mathrm{Si}(100) /\left(\mathrm{Py}-d_{\mathrm{Py}} / \mathrm{Cu}-d_{\mathrm{Cu}}\right)_{100}$, (iv) $\mathrm{Si}(100) / \mathrm{SiO}_{2} / \mathrm{Cu}-20 \mathrm{~nm} /\left(\mathrm{Py}-d_{\mathrm{Py}} / \mathrm{Cu}\right.$ $\left.-d_{\mathrm{Cu}}\right)_{100}$, (v) $\mathrm{Si}(100) / \mathrm{Cu}-20 \mathrm{~nm} /\left(\mathrm{Py}-d_{\mathrm{Py}} / \mathrm{Cu}-d_{\mathrm{Cu}}\right)_{30}$, (vi) $\mathrm{Si}(100) / \mathrm{Py}-$ $5 \mathrm{~nm} /\left(\mathrm{Py}-d_{\mathrm{Py}_{\mathrm{y}}} / \mathrm{Cu}-d_{\mathrm{Cu}}\right)_{100}, \quad 1 \leq d_{\mathrm{Py}} \leq 5 \mathrm{~nm}$. (b) Saturation magnetic moment $m_{\mathrm{S}}$ per surface area $S$ and number of periods $N$ as a function of $d_{\mathrm{Py}}$ for $\left(\mathrm{Ni}_{83} \mathrm{Fe}_{17} / \mathrm{Cu}\right)_{N}$ multilayers.

layered structure of our Mls was confirmed by the low- and the high-angle X-ray diffraction (LAXRD and HAXRD). Figure 1 shows the $\mathrm{Cu} K_{\alpha}$ HAXRD patterns for selected $\mathrm{Si}(100) / \mathrm{B} /(\mathrm{Py} / \mathrm{Cu})_{100} \mathrm{Mls}$. The samples with $\mathrm{Cu}$ buffer layer $\left(d_{\mathrm{B}}=20 \mathrm{~nm}\right)$ deposited onto $\mathrm{Si}(100)$ substrate cleaned by HF-dip exhibit the 

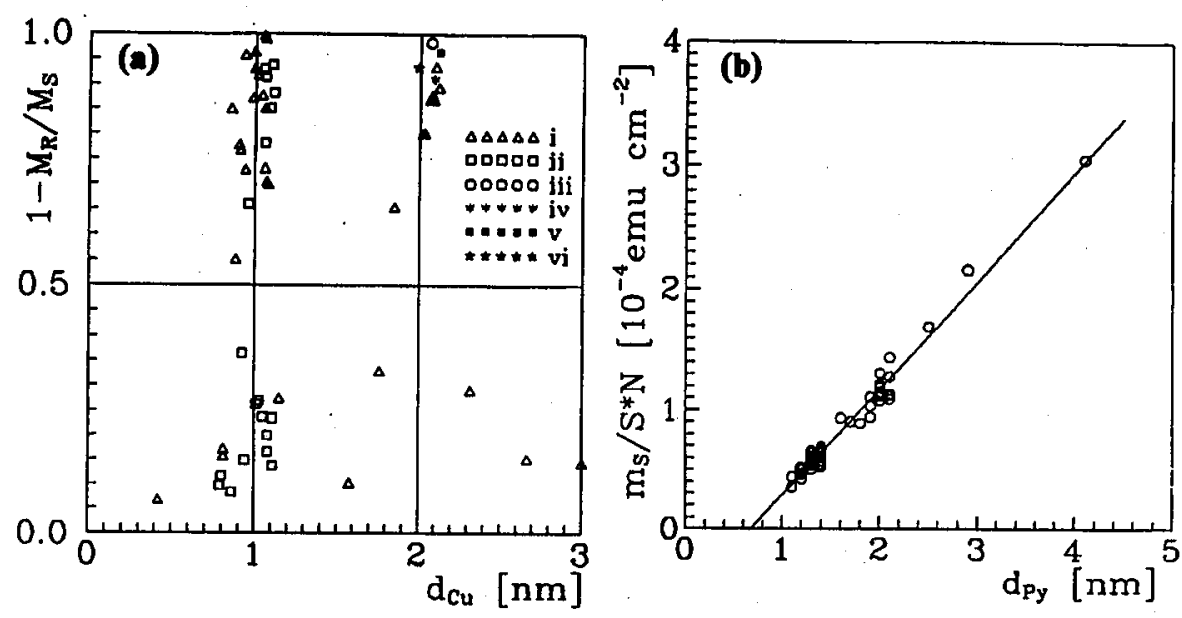

Fig. 3. Magnetization versus in-plane magnetic field $H$ for $\operatorname{Si}(100) / \mathrm{Cu}-20 \mathrm{~nm} /(\mathrm{Py}-$ $\left.d_{\mathrm{Py}} / \mathrm{Cu}-d_{\mathrm{Cu}}\right)_{100} \mathrm{Mls}$ (magnetic moment $m$ at 1800 Oe for the sample with $d_{\mathrm{Py}}=0.9 \mathrm{~nm}$ is 10 times smaller than the saturation moment for the samples with $d_{\mathrm{Py}}=2 \mathrm{~nm}$ ).

pronounced (200) diffraction from both Py and Cu sublayers (Fig. 1a). In contrast to Nakatani results [2], the domination of the (100) over the (111) texture for our films is independent of the Py and $\mathrm{Cu}$ sublayer thicknesses. For the Mls grown in other conditions, i.e., either without any HF-dip or with Py buffer, or without any buffer, the (200) reflection vanishes almost completely (Fig. 1b). It can be seen from Fig. 2a that the high values of the antiferromagnetic coupled fraction exceeding 0.95 were achieved both for the films with distinct (100) preferred orientation and for the films with the weak (111) texture. For all the samples, maxima in $F_{\mathrm{AF}}$ have been observed for $d_{\mathrm{Cu}}=1$ and $2.1 \mathrm{~nm}$. The $\mathrm{AF}$ exchange coupling strength $J_{\mathrm{AF}}=M_{\mathrm{S}} H_{\mathrm{S}} d_{\mathrm{Py}} / 4\left(H_{\mathrm{S}}\right.$ - saturation field) was determined from the hysteresis loops. For the films with $d_{\mathrm{Py}} \geq 1 \mathrm{~nm}, J_{\mathrm{AF}}=2 \times 10^{-5} \mathrm{~J} / \mathrm{m}^{2}$ at $d_{\mathrm{Cu}}=1 \mathrm{~nm}$, and $J_{\mathrm{AF}}=10^{-6} \mathrm{~J} / \mathrm{m}^{2}$ at $d_{\mathrm{Cu}}=2.1 \mathrm{~nm}$ independently of $d_{\mathrm{Py}}$ and the actual texture. For the films with $d_{\mathrm{Py}} \geq 1 \mathrm{~nm}$, the hysteresis loops are typical of $\mathrm{Mls}$ with ferro- or antiferromagnetic coupling depending on $d_{\mathrm{Cu}}$ and exhibit very small $\mathrm{H}_{\mathrm{C}} \leq 1 \mathrm{Oe}$ (Fig. 3a). The hysteresis loops for the samples with $d_{\mathbf{P y}}<1 \mathrm{~nm}$ show a Langevin-like behaviour characteristic of superparamagnetic films (Fig. $3 \mathrm{~b}$ ). It may result from an interface roughness and/or from the composition gradient across the interface. To elucidate the magnetic behaviour of the $\mathrm{Py} / \mathrm{Cu}$ interfaces, the saturation magnetic moment per surface area as a function of $d_{\mathrm{Py}}$ was plotted in Fig. 2b. The magnetization determined from the curve slope is $M_{\mathrm{S}}=880 \mathrm{G}$, a typical value for the bulk Py. The offset from the origin $(0.6 \mathrm{~nm})$ can be interpreted as a thickness of two nonferromagnetic interfaces (with zero moment at room temperature) located at each side of the Py sublayers. Superparamagnetic behaviour of $\mathrm{Py} / \mathrm{Cu} \mathrm{Mls}$ with $0.6<d_{\mathrm{Py}}<1 \mathrm{~nm}$ at room temperature may be tentatively explained as resulting from both magnetically inactive interfaces and a possible interface roughness of about $0.4 \mathrm{~nm}$. For lower temperatures, such 
films show ferromagnetic behaviour which was confirmed by FMR measurements. In conclusion, the $\mathrm{Py} / \mathrm{Cu}$ Mls deposited by the face-to-face sputtering technique show the structural and magnetic properties interesting for possible applications: (i) a well-defined layered structure and oscillatory behaviour in interlayer exchange coupling, (ii) complete AF coupling $\left(M_{\mathrm{r}} / M_{\mathrm{S}} \approx 0\right)$ of a small value $\left(2 \times 10^{-5} \mathrm{~J} / \mathrm{m}^{2}\right.$ for $d_{\mathrm{Cu}}=1 \mathrm{~nm}$ and $10^{-6} \mathrm{~J} / \mathrm{m}^{2}$ for $d_{\mathrm{Cu}}=2.1 \mathrm{~nm}$ ) for the Mls regardless of a preferred structural orientation.

\section{References}

[1] S.S.P. Parkin, Appl. Phys. Lett. 60, 512 (1992).

[2] R. Nakatani, T. Dei, Y. Sugita, Jpn. J. Appl. Phys. 31, L1417 (1992).

[3] M. Sato, S. Ishio, T. Miyazaki, J. Magn. Magn. Mater. 126, 460 (1993).

[4] M. Naoe, Y. Miyamoto, S. Nakagawa, J. Appl. Phys. 75, 6525 (1994).

[5] S.K.J. Lenczowski, Ph.D. Thesis, Eindhoven University of Technology, Eindhoven 1995.

[6] S.S.P. Parkin, Appl. Phys. Lett. 68, 1162 (1996).

[7] J. Baszyński, F. Stobiecki, B. Szymański, K. Chrzumnicka, Phys. Status Solidi A 141, K23 (1994). 